\title{
HB Q India in Two Sindhi Hindu Families of Sindh
}

\author{
Veena Kanwal $^{1}$, Jawad Hassan ${ }^{1, *}$, Shariq Ahmed ${ }^{1}$, Eisha Usman ${ }^{1}$, Nida Anwar ${ }^{1}$, Saqib Hussain Ansari², \\ Tahir Sultan Shamsi ${ }^{3}$
}

\begin{abstract}
${ }^{1}$ Department of Diagnostic Hematology, National Institute of Blood Disease \& Bone Marrow Transplantation, Karachi, Pakistan.
${ }^{2}$ Department of Pediatric Hematology, National Institute of Blood Disease \& Bone Marrow Transplantation, Karachi, Pakistan. ${ }^{3}$ Department of Clinical Hematology, National Institute of Blood Disease \& Bone Marrow Transplantation, Karachi, Pakistan.
\end{abstract}

\begin{abstract}
Hemoglobin Q is one of the alpha chain variants resulting from structural changes in alpha 1 globin gene. It is often heterozygous in form and clinically silent even in the presence of beta thalassemia trait in compound heterozygous form. We identified two Sindhi Hindu families with hemoglobin Q India, one is compound heterozygous for $\mathrm{Hb} \mathrm{Q}$ India and thalassemia trait, while other has heterozygous $\mathrm{Hb} \mathrm{Q}$ India variant. These samples were booked for routine hemoglobinopathy screening and the variant was suspected after finding an unknown peak at a retention time of 4.68 seconds, performed on high performance liquid chromatography(HPLC). For confirmation, these samples were sent for DNA analysis for the presence of suspected $\mathrm{Hb}$ Q India mutation, using amplification refractory mutation system (ARMS).
\end{abstract}

Keywords: Hemoglobin Q India, High performance liquid chromatography, ARMS PCR, Thalassaemia trait, Compound heterozygosity, Hemoglobin variant.

\section{INTRODUCTION}

Various Alpha chain haemoglobin variants have been identified in the world [1].

$\mathrm{Hb} \mathrm{Q}$ India is one of the silent haemoglobin variants with a prevalence of $0.2 \%$ to $0.4 \%$ in Indian subcontinent [2]. It results from changes in alpha 1 globin gene, substituting Arginine for Histidine at codon 64 (AAG $>$ GAG). $\mathrm{Hb}$ Q Thailand (codon 74) and $\mathrm{Hb} \mathrm{Q}$ Iran (codon 75) were the other variants found in the literature search, and these were diagnosed on the basis of the codons involved [3]. Hb Q India has a protein structure same as normal $\mathrm{Hb}$ molecule, found out on studying secondary and tertiary protein structures of these $\mathrm{Hb}$ molecules by standard bio-informatics method [4]. On alkaline $\mathrm{pH}$ electrophoresis, this variant is recognized by a band found at a position similar to $\mathrm{Hb} \mathrm{S}$ and at a retention time of 4.7 seconds on HPLC. In heterozygous state, it has also been associated with beta thalassemia trait and does not produce any manifestation. Due to the structural properties such as the residue involved, $\alpha 64$ (E 13) on the surface of the haemoglobin tetramer and charge changes at these positions do not affect the properties of the haemoglobin molecule, this $\mathrm{Hb}$ variant does not cause any haematological consequences alone [5]. Hb Q levels in heterozygous and homozygous cases can be up to $20 \%$ and $35 \%$ respectively, but if it is associated with beta-thalassaemia heterozygotes, it could be up to $14 \%$, and are decreased in beta-thalassaemia homozygotes around $9 \%$ [6]. With alpha thalassemia, $\mathrm{Hb}$ Q level can be higher up to $41.1 \%$, in one case report [7]. In India, prevalence of $\mathrm{Hb} \mathrm{Q}$ India is $0.4 \%$. It is found in western and northern India and in Sindhi families predominantly [8]. A previous study in

*Address correspondence to this author at the Department of Pediatric Hematology, National Institute of Blood Disease and Bone Marrow Transplantation, Karachi, Pakistan. E-mails: jawadkazmi2003@gmail.com
Pakistan reported this variant in various ethnic groups while highest frequency found among sindhi population [9]. Our report aims to highlight the presence of $\mathrm{Hb} \mathrm{Q}$ India in Sindhi Hindus which was found incidentally on haemoglobinopathy screening.

\section{MATERIALS AND METHODS}

Blood samples were collected in EDTA tube $(3 \mathrm{ml}), \mathrm{CBC}$ was done on Sysmex XN 1000, then high performance liquid chromatography (HPLC) of subjects were performed (Bio Rad variant II). All Samples which showed an unknown peak at retention time of 4.68 seconds (Fig. 1) were examined further by DNA analysis for the presence of suspected $\mathrm{Hb}$ Q-India mutation using amplification refractory mutation system (ARMS) after informed consent from individuals. A mutation specific primer was used to amplify region of DNA containing the mutation for $\mathrm{Hb} \mathrm{Q}-$ India in the $\alpha-1$ globin gene.

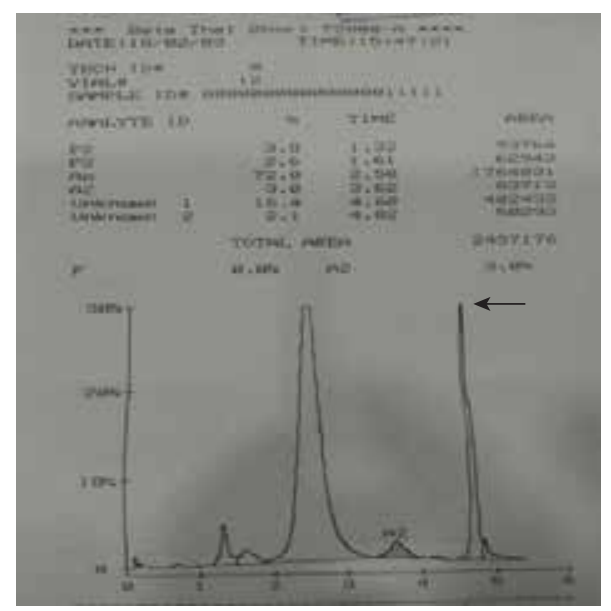

Fig. (1). HPLC Graph, Arrow Showing Peak at $4.68 \mathrm{sec}$. 
A mismatch was designed at the $3^{\prime}$ terminus of the primer to target the $\mathrm{G} \rightarrow \mathrm{C}$ mutation of $\mathrm{Hb} \mathrm{Q}$ India. PCR was carried out in a $25 \mu \mathrm{l}$ reaction containing primer concentration of 0.2 $\mu \mathrm{M}$, DMSO $1 \mu \mathrm{l}$ and 1 Unit Dream Taq DNA polymerase (thermoscientific $\AA$,USA), 25-100 ng genomic DNA was amplified. The products were examined by agarose gel electrophoresis (Fig. 2).

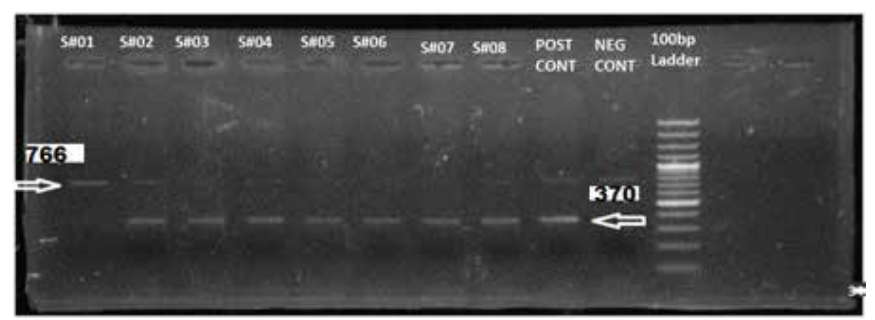

Fig. (2). ARMS-PCR: DNA Showing Amplified HB Q Specific Product of 370 Base Pairs and the Control Product of 766 Base Pairs.

\section{Case 1}

A 4 years old boy presented for screening of beta thalassemia, due to a recently diagnosed beta thalassemia major sibling. He was asymptomatic and had no clinically significant findings on examination except mild pallor. Hemogram was performed on automated SYSMEX XN 1000 and showed hypochromic microcytic anemia. HPLC was performed and an unknown peak at a retention time of 4.68 seconds was found out. ARMS-PCR was done and it came out as a mutation positive for $\mathrm{Hb} \mathrm{Q}$ India. His parents were also screened for haemoglobinopathy. Both parents were beta thalassemia minor, but father also showed similar peak at retention time of 4.68 seconds and on DNA mutation analysis, confirmed as $\mathrm{Hb} \mathrm{Q}$ India and beta thalassemia trait (Table 1).

Table 1. Case 1 - Laboratory Parameters.

\begin{tabular}{|l|c|c|c|c|c|c|c|c|}
\hline Name & $\begin{array}{c}\text { Hb } \\
\text { (g/d) }\end{array}$ & $\begin{array}{c}\text { MCV } \\
\text { (fL) }\end{array}$ & $\begin{array}{c}\text { MCH } \\
(\mathbf{p g})\end{array}$ & $\begin{array}{c}\text { HbA } \\
\mathbf{( \% )}\end{array}$ & $\begin{array}{c}\text { HbA } \\
\mathbf{( \% )}\end{array}$ & $\begin{array}{c}\text { Hb F } \\
(\mathbf{\%})\end{array}$ & $\begin{array}{c}\text { Unknown } \\
\text { peak (\%) }\end{array}$ & $\begin{array}{c}\text { DNA Analysis } \\
\text { for Hb Q India }\end{array}$ \\
\hline Subject & 9.8 & 61 & 18.2 & 78.6 & 5.2 & - & 16.7 & Positive \\
\hline Father & 12.4 & 63.9 & 18.6 & 86.1 & 4.6 & - & 9.3 & Positive \\
\hline Mother & 11.5 & 73.1 & 21.7 & 94.8 & 5.2 & - & - & - \\
\hline Sister & 7.3 & 67.5 & 19.5 & 18.5 & - & 81.5 & - & - \\
\hline
\end{tabular}

Case 2

A 25 years old male came for pre-marital screening of thalassemia. He was clinically well and have no active complaint. HPLC was performed, which showed an unknown peak at a retention time of 4.68 seconds, which was suspected as $\mathrm{Hb} \mathrm{Q}$ India and it is confirmed by ARMS-PCR. His parents and siblings ( 2 brothers and sister) were also screened, in which mother and all siblings are heterozygous for $\mathrm{Hb} \mathrm{Q}$ India. Extended family screening was done. Maternal grandmother, 2 maternal uncles and maternal cousins also have this type of haemoglobin (Table 2). Paternal family showed normal haemoglobin pattern.

Table 2. Case 2 - Laboratory Parameters.

\begin{tabular}{|c|c|c|c|c|c|c|c|c|}
\hline Name & $\underset{(\mathrm{g} / \mathrm{dl})}{\mathrm{Hb}}$ & $\begin{array}{c}\text { MCV } \\
\text { (fL) }\end{array}$ & $\begin{array}{c}\mathrm{MCH} \\
\text { (pg) }\end{array}$ & $\begin{array}{c}\text { HbA } \\
(\%)\end{array}$ & $\underset{(\%)}{\mathrm{HbA}_{2}}$ & $\begin{array}{c}\mathrm{Hb} F \\
(\%)\end{array}$ & $\begin{array}{l}\text { Unknown } \\
\text { peak }(\%)\end{array}$ & $\begin{array}{l}\text { DNA Analysis } \\
\text { for Hb Q India }\end{array}$ \\
\hline Subject & 14.5 & 85.8 & 25.4 & 81.8 & 1.9 & - & 16.3 & Positive \\
\hline Father & 12.4 & 63.9 & 18.6 & 98 & 2.0 & - & - & - \\
\hline Mother & 12.1 & 88 & 28 & 83.3 & 1.0 & - & 15.7 & Positive \\
\hline Sister & 13.5 & 86 & 27 & 82.1 & 1.2 & - & 16.7 & Positive \\
\hline Brother 1 & 15.4 & 93.9 & 30.1 & 80.4 & 3.2 & - & 16.4 & Positive \\
\hline Brother 2 & 16.1 & 98 & 34 & 81.5 & 2.3 & - & 16.2 & Positive \\
\hline Uncle1 & 15.4 & 83.3 & 27.4 & 81.1 & 2.3 & - & 16.6 & Positive \\
\hline Uncle 2 & 15.1 & 83.7 & 27.2 & 81 & 2.1 & - & 16.9 & Positive \\
\hline $\begin{array}{l}\text { Maternal } \\
\text { grandmother }\end{array}$ & 11.4 & 90.1 & 29 & 80.1 & 3.1 & - & 16.8 & Positive \\
\hline Cousin 1 & 13.6 & 100.5 & 34.3 & 79.5 & 3.2 & - & 17.3 & Positive \\
\hline Cousin 2 & 11.4 & 89.9 & 29.6 & 80.1 & 3.4 & - & 16.5 & Positive \\
\hline Cousin 3 & 12.4 & 91.3 & 29.9 & 80.1 & 3.2 & - & 16.7 & Positive \\
\hline Cousin 4 & 14.1 & 81.4 & 27.6 & 81.5 & 1.2 & - & 17.3 & Positive \\
\hline
\end{tabular}




\section{DISCUSSION}

This rare type of alpha chain variant was previously found in heterozygous state. Our both cases had been found incidentally on routine thalassemia screening, and individuals were asymptomatic. In the first case, individual and his father were compound heterozygotes for $\mathrm{Hb} \mathrm{Q}$ India and beta thalassemia trait. However in the second case, individual and the extended family were heterozygous for this variant.

The $\mathrm{Hb}, \mathrm{MCV}$, and $\mathrm{MCH}$ levels in $\mathrm{Hb} \mathrm{Q}$ trait were within normal range but those with compound heterozygotes for thalassemia trait, found out to be having lower values as previously reported [10]. In our first case $\mathrm{MCV}, \mathrm{MCH}$ was low due to concomitant beta thalassemia trait, while in second case no abnormality in MCV and $\mathrm{MCH}$ was found. Thus, it is further proved in our study that, $\mathrm{Hb} \mathrm{Q}$ heterozygotes itself do not produce any clinical abnormality, however anemia and non-specific symptoms may be due to concomitant beta thalassemia trait and possible iron deficiency anemia.

In our study, the retention time of 4.68 seconds was found as compared to 4.7 seconds, previously reported [8].

In Indian subcontinent consanguineous marriages are prevalent in muslim families $(59.6 \%)$ and therefore hemaoglobinopathies are either found in homozygous or compound heterozygous states. However, these may also be found in non-consanguineous marriages as in our cases. This might be due to presence of autosomal recessive disorders alleles in our genetic pool, resulting in marriage of two carriers of these disorders by chance, secondly as a result of interfaith marriages and might be consanguineous marriages in the ancestors as non- consanguineous marriages are not totally absent in hindu population as well(1.7\%) [11].

From our study, it has been shown that HPLC is a simple and reliable method for screening of rare haemoglobin variants like $\mathrm{Hb} \mathrm{Q}$ India as compared to alkaline $\mathrm{Hb}$ Electrophoresis. Secondly, ARMS-PCR is a useful tool for quick identification of any uncommon variant of the $\alpha$ globin or $\beta$ globin genes for which the mutation is previously known. Although definitive diagnostic method for haemoglobin variants is DNA sequencing, but it is expensive and cannot be readily performed in routine. So careful screening by HPLC and molecular confirmation by ARMS-PCR can be useful for diagnosis of haemoglobin variants.

\section{CONFLICT OF INTEREST}

Declared none.

\section{ACKNOWLEDGEMENTS}

Declared none.

\section{REFERENCES}

[1] Rathod G, Aggarwal S, Goyal R, Patel R, Bhimani RK, Kuchhal NK. Rare haemoglobin variant $\mathrm{Hb} \mathrm{J}$ Meerut in 27 years old female-a case report. Natl J Integr Res Med 2014; 5(5): 108-10.

[2] Harrison A, Mashon RS, Kakkar N, Das S. Clinico-hematological profile of $\mathrm{Hb} \mathrm{Q}$ India: An uncommon hemoglobin variant. Indian J Hematol Blood Transfus 2018; 34(2): 299-303. DOI: 10.1007/s12288-017-0864-2

[3] Wiwanitkit V. Phylogenetic tree of hemoglobin Q disorders. Internat J Hematol 2004; 2(1): 1-4. DOI: 10.5580/4c9

[4] Yadav AK. Comparative analysis of protein structure of common HB Q variants. Indian J Pathol Microbiol 2010; 53(4): 696. DOI: 10.4103/0377-4929.72039

[5] Abraham R, Thomas M, Britt R, Fisher C, Old J. HB Q-India: An uncommon variant diagnosed in three Punjabi patients with diabetes is identified by a novel DNA analysis test. J Clin Pathol 2003; 56(4): 296-9. DOI: 10.1136/jcp.56.4.296

[6] Phanasgaonkar S, Colah R, Ghosh K, Mohanty D, Gupte S. HB Q (India) and its interaction with beta-thalassaemia: A study of 64 cases from India. Br J Biomed Sci 2007; 64: 160-3. DOI: $10.1080 / 09674845.2007 .11732780$

[7 PanigrahiI, Bajaj J, Chatterjee T, Saxena R, Mahapatra M, Pati H. HB Q India: Is it always benign?. Am J Hematol 2005; 78: 245-6. DOI: 10.1002/ajh.20240

[8] Bhimani R, Rathod BG, Aggarwal S, Patel R, Goyal R, Kuchhal NK. HB Q India: An uncommon hemoglobin variant diagnosed in two patients case series. IAIM 2014; 1(4): 68-74.

[9] Moiz B, Moatter T, Hashmi MR, et al. Identification of hemoglobin Q India (alpha 1-64 Asp-His) through ARMS-PCR. First report from Pakistan. Ann Hematol 2008; 87(5): 385-9. DOI: $10.1007 / \mathrm{s} 00277-007-0431-2$

[10] Qin WB, Baysal E, Wong KF, et al. Quantities of alpha Q chain variants in heterozygotes with and without a concomitant beta-thalassemia trait. Am J Hematol 1994; 45(1): 91-3. DOI: 10.1002/ajh.2830450116

[11] Kumar R, Arya V, Agarwal S. Profiling $\beta$ Thalassemia mutations in consanguinity and nonconsanguinity for prenatal screening and awareness programme. Adv Hematol 2015; 20150 DOI: $10.1155 / 2015 / 625721$ 